\title{
Budd-Chiari syndrome
}

\author{
H. W. TILANUS \\ Department of Surgery, Erasmus University Hospital 'Dijkzigt', Dr Molewaterplein 40, 3015-GD Rotterdam, The Netherlands \\ Correspondence to: $\mathrm{Mr}$ H. W. Tilanus
}

Budd-Chiari syndrome is the generic term for different forms of hepatic venous outflow obstruction resulting in a clinical picture of portal hypertension and hepatomegaly. Three levels of venous outflow obstruction may be recognized, affecting respectively the small intrahepatic venules, the large hepatic veins and the inferior vena cava (IVC). Each level of obstruction is related to a different aetiology. Clinical manifestations range from mild symptoms to acute or chronic end-stage liver disease.
Treatment is surgical in the great majority of patients. Occlusion of the IVC may be treated by removal of the caval obstruction in selected patients. Hepatic outflow obstruction may be circumvented by different forms of shunting from the portal or upper mesenteric vein to the IVC or right atrium, depending on the level of obstruction and the difference in venous pressure. For the rare patient presenting with acute or chronic end-stage liver failure, hepatic transplantation may be a life-saving procedure.
The syndrome of portal hypertension with hepatomegaly due to hepatic venous outflow obstruction was first described by Budd'; the associated histology was first described by Chiari $^{2}$ hence the name Budd-Chiari syndrome. The outflow obstruction, caused by occlusion of the smaller or larger hepatic veins or the inferior vena cava (IVC) between the liver and the right atrium, results in right-sided upper abdominal pain, hepatomegaly and (often) massive ascites. For this review the proposal of Ludwig et al. ${ }^{3}$ is adopted: Budd-Chiari syndrome consists of hepatic venous outflow obstruction and its manifestations, regardless of cause, the obstruction being either within the liver or in the IVC. Functional hepatic outflow obstruction caused by congestive heart failure is not considered to be Budd-Chiari syndrome.

The syndrome may be specified by several characteristics; anatomical, aetiological and morphological. Although the diagnosis is quite straightforward, definitive treatment is often postponed until serious liver damage becomes apparent, and surgical intervention is associated with many complications. Several surgical procedures lay claim to superior results but, in this rare disease, it is difficult to choose the right form of hepatic venous decompression for an individual patient. This is especially so in the light of new treatment options such as liver transplantation and, more recently, transjugular intrahepatic portasystemic shunting. The aim of this review is twofold: to provide guidelines for diagnosis and therapy in general, and to describe an approach for the management of the individual patient.

\section{Aetiological considerations}

Traditionally, the level of hepatic venous occlusion in Budd-Chiari syndrome is differentiated into three groups: the small hepatic venules, the major hepatic veins and the IVC.

The first description of occlusion of the small hepatic venules by Chiari $^{2}$ used the term 'obliterative

Paper accepted 28 March 1995 endophlebitis'; today this would be regarded as venoocclusive disease. It may result from ingestion of hepatotoxins such as pyrrolizidine alkaloids ${ }^{4-7}$. Bras et al. ${ }^{8}$ described the disease in Jamaica and related it to the ingestion of 'bush teas', which contain pyrrolizidine alkaloids such as senecio and crotalaria. The same histopathological picture results from chemotherapy and radiotherapy regimens to prepare patients for bone marrow transplantation ${ }^{9,10}$. It has also been described in relation to conventional chemotherapy and to azathioprine treatment after renal transplantation ${ }^{11}$.

Occlusion of the major hepatic veins is, in many instances, secondary to an underlying disease (detected or undetected). Three main causative states may be recognized: a hypercoagulable state, malignancy and a residual group of miscellaneous diseases. A hypercoagulable state may occur in the course of various myeloproliferative syndromes, paroxysmal nocturnal haemoglobinuria, circulating lupus coagulant, Behçet's disease, and deficiencies of antithrombin III, protein $\mathrm{C}$ and protein $\mathrm{S}^{12-19}$. The use of oral contraceptives is frequently listed under the factors predisposing to Budd-Chiari syndrome ${ }^{20-23}$. In case-control studies, however, the risk of the syndrome from oral contraceptive use seems significant only in the presence of a thrombogenic tendency in patients with an underlying haematological disorder, which, at time of diagnosis of Budd-Chiari syndrome, may still be latent ${ }^{24-26}$. Increased thrombogenicity may play a role in eclampsia and in pregnancy as a cause of the syndrome, but why the major hepatic veins are the target vessels is unclear ${ }^{27-29}$. Crohn's disease and aspergillosis may cause Budd-Chiari syndrome but this is anecdotal ${ }^{30,31}$. Hepatocellular carcinoma, cysts and abscesses within the liver, and tumours outside the liver (such as rhabdomyosarcoma, leiomyosarcoma and leiomyoma) may obstruct the hepatic veins, leading to the syndrome ${ }^{32-36}$.

Occlusion of the IVC between the hepatic veins and the right atrium may be caused by a membrane, by thrombosis or by compression from outside ${ }^{37-39}$. The first description of a membranous web is attributed to Osler ${ }^{40}$ in 1879. It is a rare cause for Budd-Chiari syndrome in 
the Western world, but accounts for the majority of cases in oriental series and in South Africa ${ }^{41-43}$; it is also noted with greater frequency in areas of the USA inhabited by oriental immigrants ${ }^{44}$. There is increasing evidence that pre-existing cirrhosis and previous hepatitis predispose to a membranous obstruction and in affected patients an unusually high incidence of hepatitis $B$ positivity is found ${ }^{45-49}$. The nature of the web, acquired or congenital, is not completely clear, but membranous obstruction is extremely rare in childre ${ }^{50,51}$. The high incidence of primary diseases in these patients supports the concept of a thrombotic lesion preceding the membranous obstruction ${ }^{52}$. This view is strengthened by the careful study of Kage and colleagues ${ }^{53}$, which favoured a thrombotic nature for the membrane after an analysis of 17 autopsy cases.

\section{Pathology}

The pathological picture is different in early and late Budd-Chiari syndrome. In the acute situation the liver may be extremely enlarged, macroscopically congested and (red-purple) discoloured with blunt edges. Histological examination shows normal periportal areas in the early stages, but the perivenular liver tissue is darkened by blood congestion caused by the venous thrombosis. This

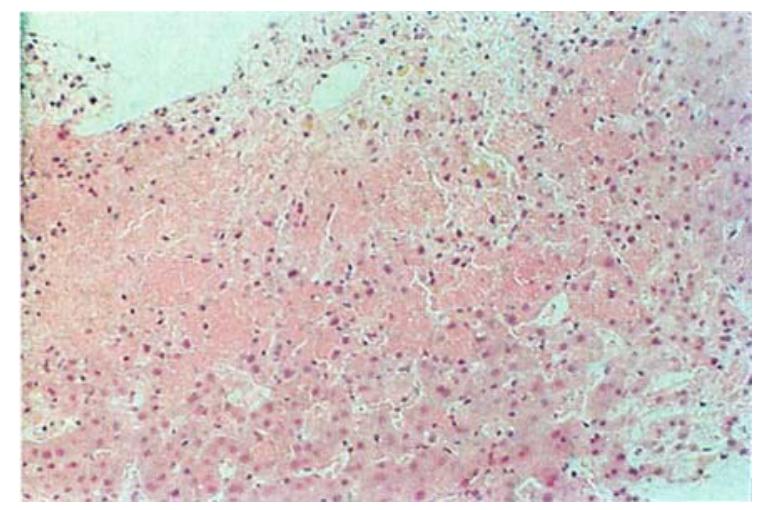

Fig. 1 Thrombosis of central veins with pericentral blood congestion and atrophy of hepatocytes

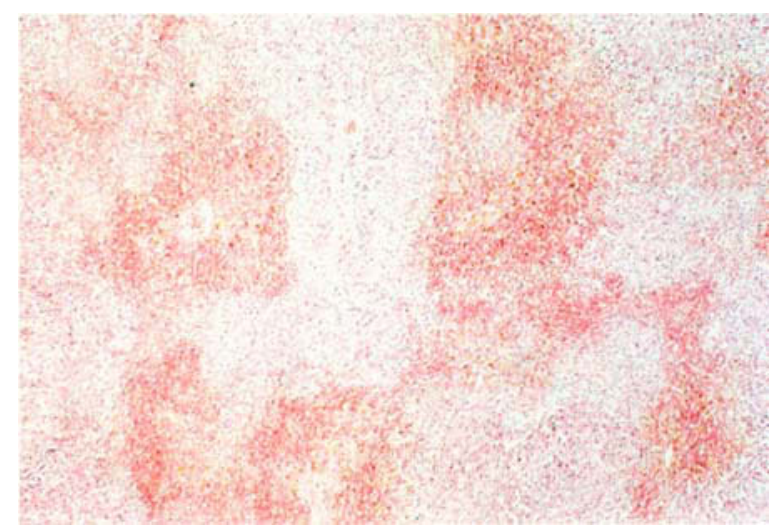

Fig. 2 Collapse of pericentral stromal tissue with bleeding and extensive death of hepatocytes. leads to atrophy and death of the centrolobular hepatocytes (Fig. 1). Following the collapse of stromal tissue, the central veins obliterate. The sinusoids become devoid of erythrocytes which are typically concentrated in the space of Disse ${ }^{54}$. Without adequate treatment the acute, and possibly reversible, situation becomes chronic and irreversible (Fig. 2). Fibrin thrombi organize as fibrous cores. Thin collagen strands replace the liver cords and the collapsed stroma, and regeneration occurs as the first sign of fibrosis and cirrhosis ${ }^{55}$. As the caudate lobe drains directly into the IVC by small and often unaffected veins, this segment may compensate for the loss of functioning liver tissue, sometimes by impressive enlargement; it may take over the function of the other affected liver segments.

\section{Clinical manifestations}

The onset of symptoms is often insidious with vague upper abdominal discomfort and progressive ascites caused by portal hypertension ${ }^{47,56}$. Mild jaundice may be present with minimal liver dysfunction at first presentation. At this early stage Budd-Chiari syndrome may mimic constrictive pericarditis ${ }^{57}$. Physical findings that suggest vena caval occlusion include leg oedema, episodes of pulmonary embolism and, sometimes, impressive varicose veins of legs, abdomen and lumbar region $^{58,59}$. Some patients with IVC occlusion, however, have no symptoms at all ${ }^{60}$. With diuretic therapy, the clinical picture may appear reassuringly improved, but such treatment is only symptomatic and increasing portal hypertension leads to oesophageal variceal haemorrhage and progressive liver failure ${ }^{61}$. In a small proportion of cases, Budd-Chiari syndrome first presents as fulminant hepatic failure; within 8 weeks of onset encephalopathy, coagulopathy and massive hepatic necrosis may occur ${ }^{62,63}$. Bismuth and Sherlock ${ }^{64}$ have proposed a classification for these different clinical manifestations of the syndrome according to the degree of concomitant liver failure: fulminant, acute, subacute and chronic.

\section{Investigations}

Ultrasonography is today the first and most important tool in the diagnosis of Budd-Chiari syndrome, with a sensitivity of over 85 per cent ${ }^{65,66}$. The absence of major hepatic vein images and the classical enlargement of the caudate lobe may be demonstrated by this technique ${ }^{67,68}$. With duplex scanning the portal and hepatic venous flow, as well as flow in the IVC, can be measured ${ }^{69-72}$ and these correlate well with venography ${ }^{73}$. Magnetic resonance imaging is capable of providing static and functional information about the hepatic veins and the IVC, but its additional value remains to be assessed ${ }^{74-77}$. Parenchymal abnormalities are best demonstrated by computed tomography, as shown in a comparative study by Miller and colleagues ${ }^{78}$. Necrotic masses or nodular regenerative hyperplasia may resemble metastases, which should be excluded by fine-needle aspiration cytology ${ }^{79-81}$. Radiocolloid scintigraphy of the liver, typically showing an increase of isotope centrally in the organ and hypertrophy of the caudate lobe, is today of only historical interest ${ }^{56,82}$.

Angiographic catheterization of the IVC and hepatic veins may show occlusion or a narrowing of the vena cava due to compression by the caudate lobe $\mathrm{e}^{83}$. If the hepatic veins can be visualized, a typical intrahepatic 'spider's 
web' may be seen $^{56,83}$. Intraluminal IVC pressure measurment and, if possible, wedge pressure measurement of the hepatic veins are mandatory. This haemodynamic information, especially a pressure gradient across the retrohepatic IVC from the bifurcation distally up to the right atrium, should be obtained and considered when surgical therapy is planned.

Of prime importance in the investigations is a liver biopsy to assess hepatocyte damage and the extent of fibrosis and cirrhosis.

\section{Management}

Untreated Budd-Chiari syndrome causes death in months or years ${ }^{84,85}$; spontaneous resolution is rarely reported. Incidental case reports are available describing successful thrombolysis in the acute situation. Urokinase, streptokinase and recombinant tissue plasminogen activator are advocated as thrombolytic agents ${ }^{86-88}$. It is difficult to understand why there should by any benefit from treatment with anticoagulants alone other than prevention of thrombus extension ${ }^{89}$, but this, in combination with diuretics, is all too often the first and sometimes the only step in the treatment of the syndrome. In general, surgery is almost always mandatory, its nature depending on the location of the outflow obstruction. Direct local treatment may be appropriate for a membrane or web in the IVC. A variety of shunt procedures are also available to which the transjugular intrahepatic portasystemic shunt (TIPS) has recently been added. Finally, liver transplantation may be the appropriate treatment for a few patients.

\section{Direct treatment}

As a web or membrane in the IVC as a cause of BuddChiari syndrome is more common in the East, the majority of series and case reports regarding direct treatment of this lesion are of Asian, Japanese and also South African origin. Percutaneous balloon angioplasty has been successful in selected cases, with a long-term follow-up of 6 years or more, sometimes after multiple procedures ${ }^{90-92}$. Lifelong anticoagulation is advised in these patients. To prevent restenosis and occlusion, prophylactic use of intravascular metal stents, such as the Wallstent (Schneider, Bulach, Switzerland) and the Gianturco stent (William Cook, Bjærverskov, Denmark) may be advisable ${ }^{93-95}$. Stenting and laser treatment of locally narrowed ostia of the hepatic veins has also been described $^{96,97}$; an alternative treatment is transcardiac membranotomy or membrane excision ${ }^{98,99}$. In more extensive obstruction involving stenosis of the IVC, cavoplasty with autologous pericardial patching under hypothermia and cardiopulmonary bypass may be carried out $^{100-103}$. Obstruction of the IVC and hepatic veins has been corrected by resection of the part of the liver containing the terminal portions of the major hepatic veins and the diseased part of the IVC, followed by direct anastomosis to the right atrium. This procedure, first described by Senning ${ }^{104}$, allows hepatic venous blood to enter the right heart directly ${ }^{105,106}$.

\section{Shunts}

The key concept of any shunt procedure is the conversion of one of the large splanchnic veins into an outflow tract

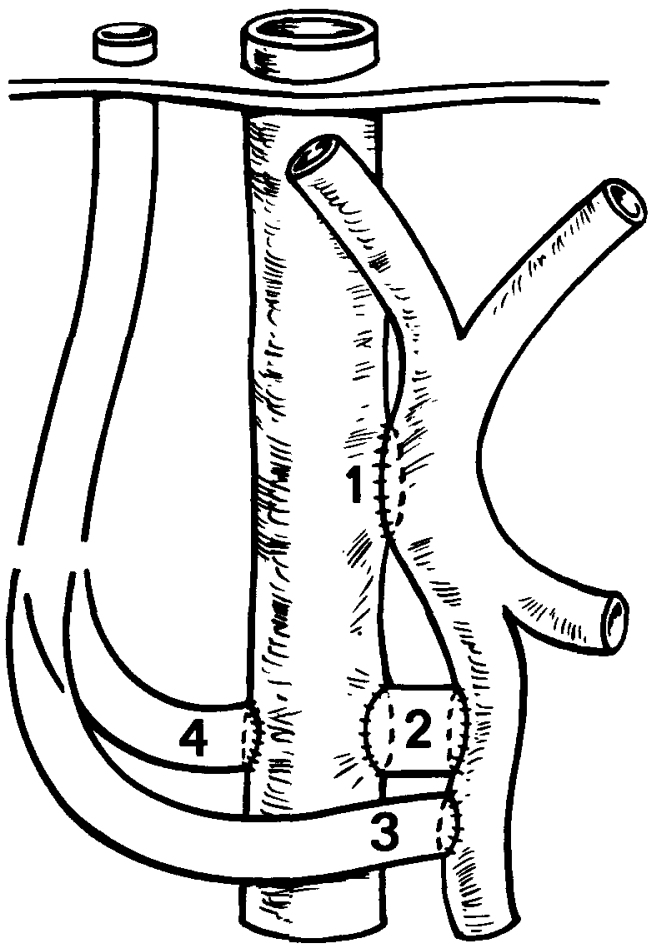

Fig. 3 Different forms of shunt: 1, portacaval shunt; 2, mesocaval shunt; 3, mesoatrial shunt; 4, cavoatrial shunt

of the congested liver and congested splanchnic area. Under these conditions the liver should be able to resume its normal function, with a reduction in portal hypertension preventing further complications. Different forms of shunting have been described in the treatment of Budd-Chiari syndrome, the choice depending on the patency of the IVC and the pressure gradient between the portal vein and vena cava. In Budd-Chiari syndrome confined to the hepatic veins, intraoperative angiography may show compression of the IVC by the caudate lobe, but no occlusion. In these circumstances the caval pressure will be in the typical range for patients with ascites, varying between 4 and $12 \mathrm{mmHg}$. In patients with caval obstruction caused by thrombosis or web formation, the IVC pressure rises easily to $20-23 \mathrm{mmHg}$. Portal or superior mesenteric vein pressures in Budd-Chiari syndrome $^{107}$ are between 20 and $25 \mathrm{mmHg}$. If intraoperative manometric studies demonstrate pressure in the retrohepatic IVC equal to or greater than those in the portal vein, portacaval or mesocaval shunting will be ineffective and result in thrombosis, as a minimum pressure gradient of $10 \mathrm{mmHg}$ is required to guarantee long-term shunt patency. In these circumstances a mesoatrial shunt is indicated (Fig. 3) ${ }^{108,109}$.

\section{Portacaval shunt}

If a shunt is indicated, the portacaval side-to-side construction is the procedure of choice only if the IVC pressure is substantially lower than the portal pressure. This shunt is performed preferably without interposition of a graft. Direct side-to-side anastomosis between the portal vein and the intrahepatic IVC is technically demanding, but it carries the highest patency rate of all 
shunts $^{108,110-112}$. Some authors regard a large caudate lobe as a contraindication or advise a partial resection, but Orloff and colleagues in their large series of more than 1400 cases have described a technique in which the direct side-to-side portacaval shunt remains free from compression by the caudate lobe; an internal jugular vein interposition graft is needed only in exceptional cases ${ }^{113,133}$. The hypertrophied caudate lobe may compress the IVC but, except in severe cases (more than 75 per cent diameter compression), this narrowing seems to be of no haemodynamic relevance. Moreover, after a successful shunt procedure the caudate lobe may return to its previous volume.

\section{Mesocaval shunt}

The mesocaval interposition $H$ shunt using homologous vena cava was first reported by Lord et al. ${ }^{114}$ and Read et al. ${ }^{115}$. In 1972 Drapanas and colleagues ${ }^{116,117}$ advocated use of a wide calibre (18-22-mm) Dacron (DuPont, Wilmington, Delaware, USA) prosthesis. The $H$ shunt is simple and avoids hilar dissection; the portal vein and the infrahepatic suprarenal IVC are not compromised, allowing possible future liver transplantation ${ }^{64,118}$. However, the price for this simplicity is a high rate of thrombotic complications, varying between 24 and 53 per cent $^{119,120}$. Cameron and colleagues ${ }^{121}$ introduced the mesocaval $C$ shunt on the wider retropancreatic part of the superior mesenteric vein. This variation prevented thrombotic complications in a series of 30 patients. Today, the widest part, which is the preferred site for the anastomosis, of the superior mesenteric vein can easily be assessed by intraoperative ultrasonography. The introduction of externally reinforced polytetrafluorethylene (PTFE) vascular grafts prompted the use of this material in mesocaval shunting, but long-term results are lacking. To overcome the thrombotic complications Bismuth and Sherlock ${ }^{64}$ prefer to use the internal jugular vein, with good results. Sixteen patients were treated with a venous mesocaval shunt, two of which thrombosed after technical complications relating to the shunt; both were successfully treated by thrombectomy.

The survival rate after shunt procedures varies widely and is directly related to the pressure difference between the portal vein and IVC, and hence to the flow in the shunt ${ }^{85,86,122}$. Once the patient has successfully recovered from surgery the prognosis and prospects of long-term survival are dictated by the underlying disease ${ }^{123,124}$.

\section{Mesoatrial shunt}

Bypass of the liver and IVC is indicated in patients in whom the IVC is (sub)totally occluded, especially in the case of coexisting obstruction of the hepatic veins for which angioplasty or membranotomy is neither indicated nor possible ${ }^{125}$. Caval compression by the caudate lobe alone is seldom an indication for mesoatrial shunting, unless the difference in venous pressure in the mesenteric vein and IVC, measured directly during operation, is so small that the patency of a portacaval or mesocaval shunt is jeopardized. The haemodynamic consequences of the stenosis, as has previously been noted, should be quantified by cavography and pressure measurements ${ }^{126,127}$. Since the first description by Cameron and Maddrey $^{125}$ in 1978, different varieties of mesoatrial shunts have been suggested ${ }^{128}$. The patency of these mesoatrial shunts varies between 75 and 100 per cent in some small series; the mean follow-up in all series is less than 2 years ${ }^{129-131}$. Others have had more discouraging results, with success rates of only 33-66 per cent ${ }^{109}$. Much attention has been paid to the technical details of the operation, and improved results have been claimed by using an external silicone rubber sleeve around a $16-\mathrm{mm}$ externally reinforced PTFE prosthesis to prevent compression of the graft by the sternum ${ }^{128}$. Warren and colleagues $^{132}$ proposed a two-step procedure: first, decompression of the venous splanchnic bed by a mesoatrial shunt, resolving the swelling of the liver and the caudate lobe, followed by a second operation after several months with closure of the mesoatrial shunt and creation of a side-to-side portacaval shunt. Orloff et al. ${ }^{133}$ reported unsatisfactory results in eight patients after mesoatrial shunting with 16-mm PTFE externally reinforced grafts. In five patients the graft occluded soon after operation, uniformly leading to death. After experimental work on cavoatrial shunting combined with side-to-side portacaval shunting, these authors' clinical results in five patients were improved, with no graft occlusion and no death. In this procedure the vascular graft receives venous blood from the obstructed splanchnic bed and from the obstructed IVC, leading to a high rate of blood flow through the graft, resulting in fewer thrombotic complications.

\section{Transjugular intrahepatic portasystemic shunt}

The elegant TIPS procedure was recently introduced for relief of portal hypertension; it has been performed in a few patients with Budd-Chiari syndrome ${ }^{134-137}$. The longterm results of TIPS insertion have not yet been evaluated and, especially in Budd-Chiari syndrome with (sub)total occlusion of the hepatic veins, cannulation is not always possible. Sometimes the shunt can be introduced through a large vein of the caudate lobe, but it is not clear whether positioning a TIPS through the only functioning part of the liver, i.e. the caudate lobe, does any good. A possible indication for a TIPS is acute bleeding, as it may allow a short-term stabilization of the patient who is awaiting definitive surgical treatment ${ }^{135,137}$. Thrombotic complications with a TIPS are common and only shortterm follow-up studies are so far available. The indications for a TIPS are not completely clear and the procedure should be reserved for patients with acute fulminant Budd-Chiari syndrome to relieve variceal bleeding before liver transplantation.

\section{Liver transplantation}

The choice between shunt or liver transplantation for Budd-Chiari syndrome is affected by several factors, the most impörtant of which is the estimated hepatic reserve. Salient features are the presence of encephalopathy, hypoalbuminaemia and hyperbilirubinaemia and, most significantly, the result of liver biopsy ${ }^{138}$. The proportion of patients with Budd-Chiari syndrome receiving a liver transplant varies widely in different series. Three groups of patients with the syndrome requiring liver transplantation in preference to a shunt may be identified: those with Budd-Chiari syndrome presenting as fulminant hepatic failure, those with end-stage chronic liver disease at first presentation and those who rapidly deteriorate after a shunt procedure ${ }^{64,139,140}$. Some studies of liver transplantation for Budd-Chiari syndrome contain a few 
patients with fulminant hepatic failure ${ }^{138,139}$, but the clinical picture may be very impressive without irreversible loss of hepatic function, so no liver transplant should be done before adequate evaluation by hepatic biopsy. In patients presenting with end-stage chronic liver failure, the decision in favour of transplantation is more straightforward ${ }^{141}$. Even here, however, a liver biopsy showing extensive fibrosis and cirrhosis is mandatory before the surgical option of a shunt is discarded ${ }^{142-144}$. The survival rate after liver transplantation for BuddChiari syndrome varies from 45 to 80 per cent after 5 years, but these figures are influenced by small numbers and better results in later series. All authors describe thrombotic complications in some patients, sooner or later, after transplantation, and so lifelong anticoagulant therapy is advised except in patients in whom a thrombogenic condition, such as antithrombin III deficiency, is corrected by the liver transplantation. Depending on the underlying aetiology, liver transplantation for Budd-Chiari syndrome may be considered as palliative, requiring long-term adjuvant therapy, or as curative, with correction of a metabolic defect $^{145-147}$.

\section{Conclusion}

Suspected Budd-Chiari syndrome should be confirmed by radiology, including venograms and pressure measurements in the IVC. Haematological or other underlying disorders should be evaluated. Based on the outcome of liver biopsy, three treatment pathways are possible. In exceptional cases liver biopsy may show neither necrosis nor fibrosis and this feature, combined with a mild clinical picture, may allow treatment by anticoagulation and administration of a diuretic. Re-evaluation should be thorough and frequent. In the majority of patients centrolobular necrosis is present without irreversible signs of fibrosis or cirrhosis. In these patients decompression by a shunt is the treatment of choice, the specific shunt depending on IVC haemodynamics. A small group of patients with severe fibrosis, or even cirrhosis, presenting with end-stage liver disease will benefit from liver transplantation, as do those with acute liver failure resulting from Budd-Chiari syndrome.

\section{References}

1 Budd G. On Diseases of the Liver. 1st ed. London: John Churchill, 1845: 146.

2 Chiari H. Ueber die Selbständige Phlebitis Obliterans der Hauptstamme der Venae Hepaticae als Todesursache. Beitr Pathol 1899; 26: 1-18.

3 Ludwig J, Hashimoto E, McGill DB, van Heerden JA. Classification of hepatic venous outflow obstruction: ambiguous terminology of the Budd-Chiari syndrome. Mayo Clin Proc 1990; 65: 51-5.

4 Stuart KL. Bras G. Veno-occlusive disease of the liver. $Q J$ Med 1957; 26: 291-315.

5 Editorial. Pyrrolizidine alkaloids. Lancet 1984; i: 201-2.

6 Bach N, Thung SN, Schaffner F. Comfrey herb tea-induced hepatic veno-occlusive disease. Am J Med 1989; 87: 97-9.

7 Kumana CR, Ng M, Lin HJ, Ko W, Wu PC, Todd D. Hepatic veno-occlusive disease due to toxic alkaloid herbal tea. Lancet 1983; ii: 1360-1(Letter).

8 Bras G, Jelliffe DB, Stuart KL. Veno-occlusive disease of the liver with non-portal type of cirrhosis, occurring in Jamaica. A M A Arch Pathol 1954; 57: 285-300.

9 Rollins RJ. Hepatic vein-occlusive disease. Am J Med 1986;
86: 297-306.

10 McDonald GB, Sharma P, Matthews DE, Shulman HM, Thomas ED. Veno-occlusive disease of the liver after bone marrow transplantation: diagnosis, incidence, and predisposing factors. Hepatology 1984; 4: 116-22.

11 Read AE, Wiesner RH, Labrecque DR et al. Hepatic venoocclusive disease associated with renal transplantation and azathioprine therapy. Ann Intern Med 1986; 104: 651-5.

12 Valla D, Casadevall $\mathrm{N}$, Lacombe $\mathrm{C}$ et al. Primary myeloproliferative disorder and hepatic vein thrombosis. A prospective study of erythroid colony formation in vitro in 20 patients with Budd-Chiari syndrome. Ann Intern Med 1985; 103: $329-34$.

13 Levy VG, Ruskone A, Baillou C, Thierman-Duffaud D, Najman A, Boffa GA. Polycythemia and the Budd-Chiari syndrome: study of serum erythropoietin and bone marrow erythroid progenitors. Hepatology 1985; 5: 858-61.

14 Valla D. Dhumeaux D, Babany G et al. Hepatic vein thrombosis in paroxysmal nocturnal haemoglobinuria. A spectrum from asymptomatic occlusion of hepatic venules to fatal Budd-Chiari syndrome. Gastroenterology 1987; 93: $569-75$.

15 Editorial. Paroxysmal nocturnal haemoglobinuria. Lancet 1992; 339: 395-6.

16 Wiedner T, Hall SE, Ortel TL, Kane WH, Rosse WF, Sims PJ. Complement-induced vesiculation and exposure of membrane prothrombinase sites in PNH platelets. Blood 1991; 78: 387(Suppl).

17 Montes de Oca MA, Babron MC, Levy M, Blétry O et al. Thrombosis in systemic lupus erythematosus: a French collaborative study. Arch Dis Child 1991; 66: 713-17.

18 Bourliere M, Le Treut VP, Arnoux D et al. Acute BuddChiari syndrome with hepatic failure and obstruction of the inferior vena cava as presenting manifestations of hereditary protein C deficiency. Gut 1990; 31: 949-52.

19 Tsuji H, Murai K, Kobayashi K et al. Multiple myeloma associated with Budd-Chiari syndrome. Hepatogastroenterology 1990; 37: 97-9 (Suppl 2).

20 Lewis JH, Tice HL, Zimmerman HJ. Budd-Chiari syndrome associated with oral contraceptive steroids. Review of treatment of 47 cases. Dig Dis Sci 1983; 28: 673-83.

21 Wu SM, Spurny OM, Klotz AP. Budd-Chiari syndrome after taking oral contraceptives. A case report and review of 14 reported cases. Am J Dig Dis 1997; 22: 623-8.

22 Grayson MJ, Reilly MCT. Budd-Chiari syndrome after oral contraceptives. BMJ 1968; i: 512-13.

23 Ecker JA, McKittrick JE, Failing RM. Thrombosis of the hepatic veins: 'The Budd-Chiari syndrome': a possible link between oral contraceptives and thrombosis formation. Am J Gastroenterol 1966; 45: 429-43.

24 Klein AS, Sitzmann JV, Coleman J, Herlong FH, Cameron JL. Current management of the Budd-Chiari syndrome. Ann Surg 1990; 212: 144-9.

25 Zafrani ES, Pinaudeau Y, Dhumeaux D. Drug-induced vascular lesions of the liver. Arch Intern Med 1983; 143: 495-502.

26 Valla D, Le MG, Poynard T, Zucman N, Rueff B, Benhamou JP. Risk of hepatic vein thrombosis in relation to recent use of oral contraceptives. A case-control study. Gastroenterology 1986; 90: 807-11.

27 Gordon SC, Polson DJ, Shirkhoda A. Budd-Chiari syndrome complicating pre-eclampsia: diagnosis by magnetic resonance imaging. $J$ Clin Gastroenterol 1990; 13: 460-2.

28 Cowchock FS. Budd-Chiari syndrome, obstetric complications, and antiphospholipid antibodies. Am J Obstet Gynecol 1991; 164: 235(Letter).

29 Ilan Y, Oren R, Shouval D. Postpartum Budd-Chiari syndrome with prolonged hypercoagulability state. $\mathrm{Am} \mathrm{J}$ Obstet Gynecol 1990; 162: 1164-5.

30 Witteman BJ, Weterman IT, Griffioen G, Lamers CB. Intestinal obstruction caused by non-absorbable tablets and Budd-Chiari syndrome in a patient with Crohn's disease. Ned Tijdschr Geneeskd 1991; 135: 766-9. 
31 Vallaeys JH, Praet MM, Roels HJ, Van Marck E, Kaufman L. The Budd-Chiari syndrome caused by a zygomycete. A new pathogenesis of hepatic vein thrombosis. Arch Pathol Lab Med 1989; 113: 1171-4.

32 Clive DM, Davidoff A, Schweizer RT. Budd-Chiari syndrome in autosomal dominant polycystic kidney disease: a complication of nephrectomy in patients with liver cysts. Am J Kidney Dis 1993; 21: 202-5.

33 Mehrotra G, Singh RP, Krishna A, Singh BK. Pyogenic liver abscess causing acute Budd-Chiari syndrome. Ann Trop Paediatr 1992; 12: 451-3.

34 Fujita H, Kawata H, Sawada T et al. Rhabdomyosarcoma in the inferior vena cava with secondary Budd-Chiari syndrome. Intern Med 1993; 32: 67-71.

35 Kracht M, Becquemin JP, Anglade MC, Mathieu D, Hillion ML, Teboul JL. Acute Budd-Chiari syndrome secondary to leiomyosarcoma of the inferior vena cava. Ann Vasc Surg 1989; 3: 268-72.

36 Lee PK, Teixeira DH, Simons JA et al. Atypical hepatic vein leiomyoma extending into the right atrium: an unusual cause of the Budd-Chiari syndrome. Can J Cardiol 1990; 6: 107-10.

37 Nakajima Y, Baba S, Nagahama T, Tazaki H. Renal cell carcinoma presenting as Budd-Chiari syndrome. Urol Int 1989; 44: 173-6.

38 Arya TV. Budd-Chiari syndrome; a not so rare presentation of renal cell carcinoma. J Assoc Physicians India 1990; 38: 956.

39 Jose B, Narayan PI, Pietsch JB et al. Budd-Chiari syndrome secondary to hepatic vein thrombosis from Wilms' tumor. Case report and literature review. J Ky Med Assoc 1989; 87: 174-6.

40 Osler W. Case of obliteration of vena cava inferior, with great stenosis of orifice of hepatic veins. J Anat Physiol 1879; 13: $291-304$.

41 Bennett IL Jr. A unique case of obstruction of the inferior vena cava. Bulletin of the Johns Hopkins Hospital 1950; 87: $290-8$.

42 Wang ZG, Zhu Y, Wang SH et al. Recognition and management of Budd-Chiari syndrome: report of one hundred cases. J Vasc Surg 1989; 10; 149-56.

43 Ohnishi K, Terabayashi H, Tsunoda T, Nomura F. BuddChiari syndrome: diagnosis with duplex sonography. Am J Gastroenterol 1990; 85: 165-9.

44 Rector WG Jr, Xu YH, Goldstein L, Peters RL, Reynolds TB. Membranous obstruction of the inferior vena cava in the United States. Medicine (Baltimore) 1985; 64: 134-43.

45 Lehmann H, Kaiserling E, Schlaak M. Left hepatic lobe atrophy and partial Budd-Chiari syndrome in a patient with alcoholic liver cirrhosis. Hepatogastroenterology 1982; 29: 3-5.

46 Simson IW. Membranous obstruction of the inferior vena cava and hepatocellular carcinoma in South Africa. Gastroenterology 1982; 82: 171-8.

47 Langnas AN, Sorrell MF. The Budd-Chiari syndrome: a therapeutic Gordian knot? Semin Liver Dis 1993; 13: 352-8.

48 Liano F, Moreno A, Matesanz R et al. Veno-occlusive hepatic disease of the liver in renal transplantation: is azathioprine the cause? Nephron 1989; 51: 509-16.

49 Lemley DE, DeLacy LM, Seeff LB, Ishak KG, Nashel DJ Azathioprine-induced hepatic veno-occlusive disease in rheumatoid arthritis. Ann Rheum Dis 1989; 48: 342-6.

50 Parker RGF. Occlusion of the hepatic veins in man Medicine 1959; 38: 369-402.

51 Boudhina T, Ghram N, Ben-Becher $S$ et al. Budd-Chiari syndrome in children. Report of 7 cases. Arch Fr Pediatr 1991; 48: 243-8.

52 Prandi D, Rueff B, Benhamou JP. Side-to-side portocaval shunt in the treatment of Budd-Chiari syndrome. Gastroenterology 1975; 68: 137-41.

53 Kage M, Arakawa M, Kojiro M, Okuda K. Histopathology of membranous obstruction of the inferior vena cava in the Budd-Chiari syndrome. Gastroenterology 1992; 102: 2081-90.
54 Leopold JG, Parry TE, Storring FK. A change in the sinusoid-trabecular structure of the liver with hepatic venous outflow block. $J$ Pathol 1970; 100: 87-98.

55 Ishak KG. Budd-Chiari syndrome: pathology. In: Seef LB, Lewis JH, eds. Current Perspectives in Hepatology. New York: Plenum Medical Books, 1989: 362-82.

56 Clain D, Freston J, Kreel L, Sherlock S. Clinical diagnosis of the Budd-Chiari syndrome. A report of six cases. Am J Med 1967; 43: 544-54.

57 Arora A, Tandon N, Sharma MP, Acharya SK. Constrictive pericarditis masquerading as Budd-Chiari syndrome. J Clin Gastroenterol 1991; 13: 178-81.

58 Dilawari JB, Bambery P, Chawla Y et al. Hepatic outflow obstruction (Budd-Chiari syndrome). Experience with 177 patients and a review of the literature. Medicine 1994; 73: $21-36$.

59 Reynolds TB. Budd-Chiari syndrome. In: Schiff L, Schiff ER, eds. Diseases of the Liver Vol. 2. 7th ed. Philadelphia, Pennsylvania: Lippincott, 1993: 1091-8.

60 Davis M, Peters R, Reynolds T. Budd-Chiari syndrome due to inferior vena cava obstruction. Gastroenterology 1968; 54: 1142-7.

61 Maddrey W. Hepatic vein thrombosis (Budd-Chiari syndrome): possible association with the use of oral contraceptives. Semin Liver Dis 1987; 7: 32-9.

62 Powell-Jackson PR, Melia W, Canalese J, Pickford RB, Portmann B, Williams R. Budd-Chiari syndrome: clinical patterns and therapy. $Q J$ Med 1982; 51: 79-88.

63 Powell-Jackson PR, Ede RJ, Williams R. Budd-Chiari syndrome presenting as fulminant hepatic failure. Gut 1986; 27: $1101-5$.

64 Bismuth H, Sherlock DJ. Portosystemic shunting versus liver transplantation for the Budd-Chiari syndrome. Ann Surg 1991; 214: 581-9.

65 Gupta S, Barter S, Philips GW, Gibson RN, Hodgson HJ. Comparison of ultrasonography, computed tomography and ${ }^{99 \mathrm{~m}} \mathrm{Tc}$ liver scan in diagnosis of Budd-Chiari syndrome. Gut 1987; 28: 242-7.

66 Bolondi L, Gaiani S, Li-Bassi et al. Diagnosis of BuddChiari syndrome by pulsed Doppler ultrasound. Gastroenterology 1991; 100: 1324-31.

67 Baert AL, Fevery J, Marchal G et al. Early diagnosis of Budd-Chiari syndrome by computed tomography and ultrasonography: report of five cases. Gastroenterology 1983; 84: $587-95$.

68 Mori H, Maeda H, Fukuda T et al. Acute thrombosis of the inferior vena cava and hepatic veins in patients with BuddChiari syndrome. CT demonstration. AJR Am J Roentgenol 1989; 153: 987-91.

69 Grant EG, Perrella R, Teseler FN, Lois J, Busuttil R. Budd-Chiari syndrome: the results of duplex and color Doppler imaging. AJR Am J Roentgenol 1989; 152: 377-81.

70 Even-Sapir E, Iles SE, Barnes DC. Liver scan in BuddChiari syndrome. Correlation with $\mathrm{CT}$ and Doppler. Clin Nucl Med 1993; 18: 706-8.

71 Ohnishi K. Terabayashi H, Tsunoda T, Nomura F. BuddChiari syndrome: diagnosis with duplex sonography. $\mathrm{Am} \mathrm{J}$ Gastroenterol 1990; 85: 165-9.

72 Ralls PW, Johnson MB, Radin DR, Boswell WD Jr, Lee KP, Halls JM. Budd-Chiari syndrome: detection with color Doppler sonography. AJR Am J Roentgenol 1992; 159: 113-16.

73 Millener P, Grant EG, Rose S et al. Color Doppler imaging findings in patients with Budd-Chiari syndrome: correlation with venographic findings. $A J R$ Am J Roentgenol 1993; 161: 307-12.

74 Fisher MR, Wall SD, Hricak H, McCarthy S, Kerlan RK. Hepatic vascular anatomy on magnetic resonance imaging. AJR Am J Roentgenol 1985; 144: 739-46.

75 Stark DD, Hahn PF, Trey C, Clouse ME, Ferruci JT Jr. MRI of the Budd-Chiari syndrome. AJR Am J Roentgenol 1986; 146: $1141-8$

76 Park JH, Han JK, Choi BI, Han MC. Membranous obstruction of the inferior vena cava with Budd-Chiari 
syndrome: MR imaging findings. J Vasc Interv Radiol 1991; 2: $463-9$.

77 Friedman AC, Ramchandani P, Black M, Caroline DF, Radecki PD, Heeger P. Magnetic resonance imaging diagnosis of Budd-Chiari syndrome. Gastroenterology 1986; 91: 1289-95.

78 Miller WJ, Federle MP, Straub WH, Davis PL. BuddChiari syndrome: imaging with pathologic correlation. Abdom Imaging 1993; 18: 329-35.

79 Arora A, Seth S, Sharma MP, Acharya SK, Mukhopadhayaya S. Case report: unusual CT appearances in a case of Budd-Chiari syndrome. Clin Radiol 1991; 43: $431-2$.

80 de Sousa JM, Portmann B, Williams R. Nodular regenerative hyperplasia of the liver and the Budd-Chiari syndrome. Case report, review of the literature and reappraisal of pathogenesis. J Hepatol 1991; 12: 28-35.

81 Castellano G, Canga F, Solis-Herruzo JA, Colina F, Martinez-Montiel MP, Morillas JD. Budd-Chiari syndrome associated with nodular regenerative hyperplasia of the liver. J Clin Gastroenterol 1989; 11: 698-702.

82 Tavill AS, Wood EJ, Kreel L, Jones EA, Gregory M, Sherlock S. The Budd-Chiari syndrome: correlation between hepatic scintigraphy and the clinical, radiological, and pathological findings in nineteen cases of hepatic venous outflow obstruction. Gastroenterology 1975; 68: 509-18.

83 Kreel L, Freston JW, Clain D. Vascular radiology in the Budd-Chiari syndrome. Br J Radiol 1967; 40: 755-9.

84 Mitchell MC, Boitnott JK, Kaufman S, Cameron JL, Maddrey WC. Budd-Chiari syndrome: etiology, diagnosis and management. Medicine 1982; 61: 199-218.

85 McCarthy $P$. van Heerden J, Adson M, Schafer LW, Wiesner RH. The Budd-Chiari syndrome: medical and surgical management of 30 patients. Arch Surg 1985; 120 : $657-62$.

86 Greenwood LH, Yrizarry JM, Hallet JW Jr, Scoville GS Jr. Urokinase treatment of Budd-Chiari syndrome. AIR Am J Roentgenol 1983; 141: 1057-9.

87 Sholar PW, Bell WR. Thrombolytic therapy for inferior vena cava thrombosis in paroxysmal nocturnal haemoglobinuria. Ann Intern Med 1985; 103: 539-41.

88 Cassel GA, Morley JE. Hepatic vein thrombosis treated with streptokinase. $S$ Afr Med J 1974; 48: 2319-20.

89 McDermott WV, Stone MD, Bothe A Jr, Trey C. BuddChiari syndrome. Historical and clinical review with analysis of surgical corrective procedures. Am J Surg 1984; 147: $463-7$.

90 Sharma S, Loya YS, Daxini BV. Percutaneous balloon membranotomy combined with prolonged streptokinase infusion for management of inferior vena cava obstruction. Am Heart J 1992; 123: 515-18.

91 Langnas AN, Sorrell MF, Donovan JP, Shaw BW Jr. Surgical management of the Budd-Chiari syndrome: no place for a procrustean bed. Hepatology 1992; 16: 1303-5.

92 Martin LG, Henderson JM, Millikan WR Jr, Casarella WJ, Kaufman SL. Angioplasty for long-term treatment of patients with Budd-Chiari syndrome. AJR Am J Roentgenol 1990; 154: 1007-10.

93 Weernink EEM, Huisman AB, ten-Napel CHH. Treatment of Budd-Chiari syndrome by insertion of wall-stent in hepatic vein. Lancet 1991; 338: 644(Letter).

94 Dick R, Hobbs KEH. Metal stents in Budd-Chiari syndrome. Lancet 1991; 338: 1075(Letter).

95 Lopez RR Jr, Benner KG, Hall L, Rosch J, Pinson CW. Expandable venous stents for treatment of the Budd-Chiari syndrome. Gastroenterology 1991; 100: 1435-41.

96 Walker HS, Rholl KS, Register TE, van Breda A. Percutaneous placement of a hepatic vein stent in the treatment of Budd-Chiari syndrome. $J$ Vasc Interv Radiol 1990; 1: 23-7.

97 Furui S, Yamauchi T, Ohtomo K, Tsuchiya K, Makita K, Takenaka E. Hepatic inferior vena cava obstructions: clinical results of treatment with percutaneous transluminal laser-assisted angioplasty. Radiology 1988; 166: 673-7.

98 Hirooka M, Kimura C. Membranous obstruction of the hepatic portion of the inferior vena cava. Surgical correction and etiological study. Arch Surg 1970; 100: 656-63.

99 Kimura L, Matsuda S, Koie H, Hirooka H. Membranous obstruction of the hepatic portion of the inferior vena cava: clinical study of nine cases. Surgery 1972; 72: 551-9.

100 Murphy JP Jr, Gregoric I, Cooley DA. Budd-Chiari syndrome resulting from a membranous web of the inferior vena cava: operative repair using profound hypothermia and circulatory arrest. Ann Thorac Surg 1987; 43: 212-14.

101 Dohi K, Asahara T, Tukuda Y et al. Successful treatment by simultaneous hepatic venoplasty and cavoplasty for BuddChiari syndrome with obstruction of retrohepatic inferior vena cava. Surgery 1993; 113: 574-9.

102 Ahn SS, Goldstein LI, Bussutil RW. Simultaneous retrohepatic inferior cavoplasty and side-to-side portocaval shunt for recurrent thrombosed mesoatrial shunt in the Budd-Chiari syndrome. Surgery 1987; 101: 165-71.

103 Yamamoto S, Yokoyama Y, Takeshige K, Iwatsuki S. Budd-Chiari syndrome with obstruction of the inferior vena cava. Gastroenterology 1968; 54: 1070-84.

104 Senning A. Transcaval posterocranial resection of the liver as treatment of the Budd-Chiari syndrome. World J Surg 1983; 7: 632-40.

105 Nakao K, Miyata M, Nagaoka M et al. Budd-Chiari syndrome treated by Senning's procedure. J Cardiovasc Surg (Torino) 1988; 29: 746-50.

106 Pasic M, Senning A, von Segesser L, Carrel T, Turina M. Transcaval liver resection with hepatoatrial anastomosis for treatment of patients with the Budd-Chiari syndrome. Late results. J Thorac Cardiovasc Surg 1993; 106: 275-82.

107 Orlof MJ. Budd-Chiari syndrome and veno occlusive disease. In: Blumgart LH, ed. Surgery of the Liver and Biliary Tract. Edinburgh: Churchill Livingstone, 1988: 1425-53.

108 Orloff MJ, Orloff MS, Daily PO. Long-term results of treatment of Budd-Chiari syndrome with portal decompression. Arch Surg 1992; 127: 1182-8.

109 Henderson JM, Warren WD, Millikan WJ Jr et al. Surgical options, hematologic evaluation, and pathologic changes in Budd-Chiari syndrome. Am J Surg 1990; 159: 41-8.

110 Pezzuoli G, Spina GP, Opocher E, Galeotti F, Zannini P. Portacaval shunt in the treatment of primary Budd-Chiari syndrome. Surgery 1985; 98: 319-23.

111 Klein AS, Cameron JL. Diagnosis and management of the Budd-Chiari syndrome. Am J Surg 1990; 160: 128-33.

112 Orloff MJ, Johansen KH. Treatment of Budd-Chiari syndrome by side-to-side portacaval shunt: experimental and clinical results. Ann Surg 1978; 188: 494-512.

113 Orloff MJ, Girard B. Long-term results of Budd-Chiari syndrome by side to side portacaval shunt. Surg Gynecol Obstet 1989; 168: 33-41.

114 Lord JW Jr, Rossi G, Daliana M, Rosati LM. Mesocaval shunt modified by the use of a Teflon prosthesis. Surg Gynecol Obstet 1970; 130: 525-6.

115 Read RC, Thompson BW, Wise WS, Murphy ML. Mesocaval $H$ venous homografts. Arch Surg 1970; 101: $785-91$.

116 Drapanas T. Interposition mesocaval shunt for treatment of portal hypertension. Ann Surg 1972; 176: 435-48.

117 Drapanas T, LoCicerco J III, Dowling JB. Hemodynamics of the interposition mesocaval shunt. Ann Surg 1975; 181: 523-33.

118 Brems JJ, Hiatt JR, Klein AS et al. Effect of a prior portosystemic shunt on subsequent liver transplantation. Ann Surg 1989; 209: 51-6.

119 Terpstra OT, Ausema B, Bruining HA et al. Late results of mesocaval interposition shunting for bleeding oesophageal varices. Br J Surg 1987; 74: 787-90.

120 Reznick RK, Langer B, Taylor BR, Lossing A, Blendis LM, Colapinto RF. Results and hemodynamic changes after interposition mesocaval shunt. Surgery 1984; 95: 275-80.

121 Cameron JL, Harrington DP, Maddrey WC. The mesocaval 'C' shunt. Surg Gynecol Obstet 1980; 150: 401-3. 
122 Cameron JL, Herlong HF, Sanfey $\mathrm{H}$ et al. The Budd-Chiari syndrome. Treatment by mesenteric-systemic venous shunts. Ann Surg 1983; 198: 335-46.

123 Ahn S, Yellin A, Shenji F, Colonna JO, Goldstein LI, Busuttil RW. Selective surgical therapy of the Budd-Chiari syndrome provides superior survivor rates than conservative medical management. J Vasc Surg 1987; 5: 28-37.

124 Van Steenbergen W, Beyls J, Vermylen J et al. 'Lupus' anticoagulant and thrombosis of the hepatic veins (BuddChiari syndrome). Report of three patients and review of the literature. J Hepatol 1986; 3: 87-94.

125 Cameron JL, Maddrey WC. Mesoatrial shunt: a new treatment for the Budd-Chiari syndrome. Ann Surg 1978; 187: 402-6.

126 Stringer MD, Howard ER, Green DW, Karani J, Gimson AS, Williams R. Mesoatrial shunt: a surgical option in the management of the Budd-Chiari syndrome. Br J Surg 1989; 76: $474-8$.

127 Raby N, Karani J, Meire H, Michell M, Howard E. BuddChiari syndrome: shunt selection and post-operative assessment. Clin Radiol 1989; 40: 586-90.

128 Cameron JL, Kadir S, Pierce WS. Mesoatrial shunt: a prosthesis modification. Surgery 1984; 96: 114-16.

129 Millikan WJ Jr, Henderson JM, Sewell CW et al. Approach to the spectrum of Budd-Chiari syndrome: which patients require portal decompression? Am J Surg 1985; 149: 167-76.

130 Chezmar JL, Bernadino ME. Mesoatrial shunt for the treatment of Budd-Chiari syndrome: radiologic evaluation in eight patients. AJR Am J Roentgenol 1987; 149: 707-10.

131 Wang $\mathrm{Z}$, Zhu $\mathrm{Y}$, Wang $\mathrm{S}$ et al. Recognition and management of Budd-Chiari syndrome: report of one hundred cases. J Vasc Surg 1989; 10: 149-56.

132 Warren WD, Potts JR, Fulenwider JT, Millikan WJ Jr, Henderson JM. Two stage surgical management of the Budd-Chiari syndrome associated with obstruction of the inferior vena cava. Surg Gynecol Obstet 1984; 159: 101-7.

133 Orloff MJ, Daily PO, Girard B. Treatment of Budd-Chiari syndrome due to inferior vena cava occlusion by combined portal and vena caval decompression. Am J Surg 1992; 163: 137-42.

134 Walter E, Muntwyler J, Bertschinger P et al. Transjugular intrahepatischer portosystemischer Stent-Shunt (TIPS) bei einem patienten mit Budd-Chiari syndrom. Schweiz Med Wochenschr 1993; 11: 1696-1702.
135 Ochs A, Sellinger M, Haag Ket al. Transjugular intrahepatic portosystemic stent-shunt (TIPS) in the treatment of BuddChiari syndrome. J Hepatol 1993; 18: 217-25.

136 Peltzer MY, Ring EJ, LaBerge JM, Haskal ZJ, Radosevich PM, Gordon RL. Treatment of Budd-Chiari syndrome with a transjugular intrahepatic portosystemic shunt. $J$ Vasc Inten Radiol 1993; 4: 263-7.

137 LaBerge JM, Ring EJ, Lake JR et al. Transjugular intrahepatic portosystemic shunts: preliminary results in 25 patients. J Vasc Surg 1992; 16: 258-67.

138 Shaked A, Goldstein RM, Klintmalm GB, Drazan K, Husberg B, Busuttil RW. Portosystemic shunt versus orthotopic liver transplantation for the Budd-Chiari syndrome. Surg Gynecol Obstet 1992; 174: 453-9.

139 Sakai Y, Wall WJ. Liver transplantation for Budd-Chiari syndrome: a retrospective study. Surg Today 1994; 24: 49-53.

140 Thompson NP, Miller AD, Hamilton G, Alexander GMJ, Friend PJ, Burroughs AK. Emergency rescue hepatic transplantation following shunt surgery for Budd-Chiari syndrome. Eur J Gastroenterol Hepatol 1994; 6: 835-7.

141 Halff G, Todo S, Tzakis AG, Gordon RD, Starzl TE. Liver transplantation for the Budd Chiari syndrome. Ann Surg 1990; 211: 43-9.

142 McMaster P. Budd-Chiari syndrome: shunt or transplant? HPB Surgery 1994; 7: 257-9.

143 Knoop M, Lemmers HP, Bechstein WO et al. Treatment of the Budd-Chiari syndrome with orthotopic liver transplantation and long-term anticoagulation. Clin Transplant 1994; 8: 67-72.

144 Panis Y, Belghiti J, Valla D, Benhamou JP, Fekete F. Portosystemic shunt in Budd-Chiari syndrome: long-term survival and factors affecting shunt patency in 25 patients in Western countries. Surgery 1994; 115: 276-81.

145 Goldstein R, Clark P, Klintmalm G, Husberg B, Gonwa T, Stone M. Prevention of recurrent thrombosis following liver transplantation for Budd-Chiari syndrome associated with myeloproliferative disorders: treatment with hydroxyurea and aspirin. Transplant Proc 1991; 23: 1559-60.

146 Schattenfroh N, Bechstein WO, Blumhardt $G$ et al. Liver transplantation for PNH with Budd-Chiari syndrome. A case report. Transpl Int 1993; 6: 354-8.

147 Lang H, Oldhafer KJ, Kupsch E, Ringe B, Pichlmayr R. Liver transplantation for Budd Chiari syndrome - palliation or cure? Transpl Int 1994; 7: 115-19. 